\title{
The Application and Development Trend of Micro-course in College English Teaching
}

\author{
Xiaohua Zhang \\ School of Foreign Studies, Xi'an University, 710065
}

Keywords: Micro-course; College English teaching; Application and development; Trend

\begin{abstract}
In recent years, China has strengthened exchanges with other countries in the aspects of politics, economy and culture, and higher demands were put forward on listening, speaking, reading and writing. Therefore, how to improve the quality and level of college English teaching has become a serious problem for college English teachers, in which micro-course as a new teaching method in college English teaching has been widely used. This article aims to investigate the application and development trend of the micro-course in college English teaching, to help English teachers improving their teaching level, to optimize the quality of teaching, and to create a modern classroom that meet the development of the times.
\end{abstract}

\section{Introduction}

The micro-course is a teaching method developed on the basis of information technology. Its appearance, on the one hand, broken the conventional teaching methods, developed a more refined, innovative way of teaching. On the other hand, it also filled the lack of traditional teaching methods, and effectively improved the efficiency of teaching teachers. Nowadays, in college English teaching, teachers pay more and more attention to the improvement of educational methods and the widening of educational channels. As a new educational resource, the micro - class has aroused the increasing attention of English teachers.

\section{The Basic Connotation of Micro Course}

"Micro-course", as the name suggests, it refers to a short course. It is the use of information technology, in accordance with the laws of human perception, showing fragmented learning content, learning process and expanding the material structure of digital resources. Its core is a brief teaching video, and its main feature is that the time is short, and the content is less but fine, highlight the theme, showing a variety of forms, interesting presentation, feedback timely, targeted clearly and so on. Although the average duration of the micro-course only has 5-10 minutes, or even only 1-2 minutes, but its content covers the teaching topics related to the various important elements, such as teaching design, learning materials, contact test, teacher-student interaction and other teaching resources. It was deeply loved by the lecturers and the classmates.

Although the content and form of micro-course seem to be "fragmented", its target is clear with concentrated target population, and it can maintain its own system, furthermore, the combination of micro-course can achieve the comprehensiveness of teaching knowledge. As an auxiliary method, micro-course only plays its role in the traditional classroom on the basis of the role, and cannot completely replace the traditional classroom.

\section{The Basic Way of Applying Micro-course in College English Teaching}

Due to the long-term acceptance of exam-oriented education oppression, many Chinese students' learning methods have largely changed to a spoon-type memory model. This kind of passive learning method will cause them to lose interest in English learning, and find it difficult to accept new knowledge. After entering university, many people are in a state of lazy. As without the pressure of study, they no longer have the motivation to learning, and this phenomenon is particularly evident in college English class. With this kind of develop trend, it is bad for the 
comprehensive development and career development of college students. Meanwhile, it also has adverse impacts on the teachers' education level, and making the English learning more and more difficulty for lots of students.

\section{The Integration of English Teaching and Micro-Courses Characteristics}

Learning a foreign language that is completely different from their native language is extremely difficult for many Chinese students. On the one hand, the way of teachers' teaching and the contents they convey cannot completely absorb by everyone. For students with strong absorptive capacity, teachers can make a quick learning, but for students with less absorptive abilities, even in-depth and repetitive memories cannot make them fully understand the point of knowledge. However, passive learning largely relied on the memory. This is not the right way to learn English. On the other hand, without practicing and familiar environment, students are unable to apply their knowledge, and hard to understand the sense of language, which consequently increase the difficulty of learning. As the saying goes, "practice makes perfect", which is particularly important in language learning. The micro-course, therefore, was applied to the English teaching class can combine both of them for students and teachers, and have a dual effect on promoting.

On the First Stage, the Introduction of the Micro-Course for Stimulating Students' Learning Enthusiasm. Micro-course has various forms, such as animation, sitcom, music and other forms. It's good to play a video or music on class for students relaxes their mind when they generate aesthetic fatigue to the lecture. In this way, they will have expectation to the daily course. As the contents of each lesson are not the same, so it is enough to keep students fresh in class. Only students show interest in the content of learning, they can accept it from the heart.

On the Second Stage, Systematization of Micro-Course Content. When students' learning enthusiasm was aroused, teachers should strive to link the micro-course content with the teaching content, making a happy classroom atmosphere for student to master the knowledge. How to reasonable divide and refine the teaching contents will be a test for teachers. At the same time, it can allow teachers to have more time in rethinking their teaching, and constantly improve their teaching levels. For important and difficult knowledge points, different forms of micro-course or the same form of micro-course are needed, which can strengthen students' knowledge points and will not make students feel uncomfortable.

On the Third Stage, the Use of Micro-Course in Classroom Practice. English is a language, which should be used frequently in order to produce a sense of language. Therefore, micro-course can be used as an example to guide students to open their mouths in the classroom, express their views and have mutual exchange. In that case, they can discover their own deficiencies and correct their own mistakes. It not only improves English reading and writing skills, but also increases their own oral level largely.

On the Fourth Stage, Incensement of Teacher-Student Interaction. Teachers can invite students to express their own ideas in order to understand what kind of forms of micro-course they like, and fully understand their inner thoughts and needs. On the other hand, you can also give the appropriate opportunity, or in the form of post-homework, to enable students make their own micro-course. By doing so, teachers can discover what kind of focus their students pay attention to, it also help to improve the students' comprehensive ability.

\section{The Construction of English Teaching and Micro-Course Mode}

The content of micro-course is fragmented, and the time of each micro-course is very short, so the whole class cannot occupy by the micro-course study. As over-time micro-course may lead to uncomfortable for students. More importantly, we cannot lose the purpose of teaching, and totally deny the advantages of traditional teaching methods. Therefore, how to use the limited classroom is the test of teachers, which requires teachers to well arrange the teaching content, to build a reasonable model for English teaching and micro classes. Teachers can use micro-course as the main mode of teaching for pre-class preview, class exercises, after-school review. First of all, micro-course was used before a starting class to build a learning atmosphere for students. After a period of traditional teaching, teacher can apply the micro-course into the classroom again in order to active the classroom atmosphere, thus to strengthen the previous knowledge. After class students 
can use the micro-course for after-school reviewing. The micro-course not only can be used for homework assignment, but also for re-summary of knowledge points, by doing this, students can better absorb the knowledge points. Of course, according to different teaching demand, teachers can develop different models, so as to better improve the quality of education.

\section{The Construction of English Teaching and Micro Subjects}

In the traditional English teaching classroom, the teacher is the main part, which can not guarantee that each student can participate in classroom learning, and teachers do not have enough energy to supervise each student. The combination of traditional English teaching and micro-class can properly transfer the relationship of teacher and student. Students actively participate in the classroom activities and give full play to their subjective initiative can not only conducive to their attention concentration and interesting development, but also greatly help teachers to manage the classroom.

\section{Third, the Application of Micro-courses in College English Teaching Trends}

\section{Build a Systematic Application of Micro-Class Resources}

At present, the form of micro-class has been applied in college English teaching class, but the mode of micro-class resources is not perfect, and the main model that using in the class is the game model. Teachers are in the stage of accepting new things with chaotic ideas in mind, thus the design of micro-course has a variety of forms, but the content are relatively weak. They inclined to explain and expand a single difficulty point or knowledge point. Moreover, these micro-courses can be easily obtained from many open network platform. It is true that the current forms of micro-course are rich and colorful, and the content of the knowledge points is relatively independent. This kind of model is conducive to increasing the overall number of resources. However, on the other hand, there is no systematic management of resources, which will make the proliferation of resources have no focus. In this way, higher requirements are put forward for teachers or micro-class designers. It requires them to gradually achieve an excellent design of micro-course. An excellent micro-course video should fully integrate the grammar and knowledge points, show clearly theme of micro-course, easy to understand. On this basis, it is able to gradually improve the design levels of micro-class content and micro-class teaching. In addition, when using the micro-class for teaching, teachers are needed to find the connection and classification among micro-courses, so as to optimize the structure of micro-class, making micro-course as the unity of subjectivity. Thus, students can learn to learn more systematic and coherent knowledge and facilitate students to master and reserve the knowledge, so that the micro-course can burst of long life vitality.

\section{Create a Platform for the use of Micro-Class Resources}

The essence of micro- course is the network mode of teaching formed on based on the network platform. With the development of information technology, the network has been deeply affecting the students' life and learning process. They are willing to spend more time on the Internet and maintain a friendly attitude to the network.

Therefore, when the micro-class designers integrate the micro-course as a resources system, and then shared these micro-courses onto the network platform. it is enable students to build their own shared learning platform. As the unified management of the learning platform is not only conducive to reducing the students' time on resource screening, but also help students precisely choice their own learning resources. The role of sharing learning platform not only provides students with a platform for learning, but also a teaching feedback platform for helping teachers' teaching. First of all, micro-courses are needed to be classified in accordance with certain rules to facilitate students' selection and learning, to develop students' sense of self-judgment, to enhance students' self-learning ability. Second, through the background operation of the platform, teachers can test the students' learning situation. First, it can monitor the average amount of students on the line, to understand their login learning situation. Second, it can monitor the correct rate of the students' homework, and understand the weakest learning parts of student, so as to strengthen these weak parts. Once again, through the click rate to determine which courses are more attractive among students, which courses are also need to be improved, so as to enhance the level of teachers and 
micro-class producers.

To sum up, micro-course and traditional classroom should form a model of complementary and mutual promotion in order to play the biggest advantage of both sides. So as to further help students to learn their own English, and help teachers optimize their teaching quality.

\section{Promote the Sharing of Micro-Course Resources Integration}

Resource sharing is a favorable way to achieve communication, each university has its own teaching methods and advantages, and each of the micro-course designers has different understanding and perception on the concept of micro-class. At present, many colleges and universities have a network of electronic resources sharing platform in order to achieve cross-school exchanges and cooperation. College English teachers should supervise and help the construction and use of this resource sharing platform. The share of English teaching and learning resources, on the one hand, can help students achieving cross-school communication, break through the barriers of education barriers, and promote the establishment of university friendship. On the other hand, it helps to the study exchange among teachers; take length of human, make up short oneself. Only communication can reflect the value of information.

There is no doubt that micro-course play an important role in promoting the quality of English classroom teaching, but that it does not mean that teachers should ignore the advantages of traditional teaching methods. Therefore, in the English classroom teaching, teachers should pay attention to the integration of micro-class and traditional teaching methods, and give full play to the advantages of both, and actively explore effective teaching methods, so as to improve the quality of English classroom teaching.

\section{Conclusion}

The central idea of this paper is that modern English teaching classroom should introduce the new teaching mode of micro-course, stimulate students 'enthusiasm for learning and cultivate students' interest in English learning, thus to gradually transfer students from a passive learner to a active learner. Teachers and micro-class designers should explore a reasonable combination of micro-class and traditional classroom model, and make both of them build up on each other and complement each other.

For multifarious micro-course resources, information reorganization and classification and the achievement of the unified management of resources are important. Remove the dross, and choose its essence, it is good to provide students with a good English learning environment. Colleges and universities should build a platform for sharing English micro-class resources, so that students and teachers can learn from each other, promote each other. Only in this way we can make English learning easier and make English a valuable treasure for students.

\section{Reference}

[1]M. Peng, The application of "tilting classroom" and micro-course teaching in college English reading and writing. J Hubei Univ Economics (Humanities and Social Sci). 02 (2015) 208-209.

[2]F. Ji, M. Pan. Research on the application of "tilting classroom" model based on micro-course in college English listening teaching. Crazy English (Teacher Edition). 04 (2014) 32-34.

[3] M. Huang. Construction and application of teaching mode of micro-course under the perspective of cognitive linguistics - taking college English audio-visual course as an example. Sci Technol Guide (late). 02 (2016) 99-100.

[4] M. H. Du. Construction and application of teaching mode of micro-course under the perspective of cognitive linguistics - taking college English audio-visual course as an example, Chin $\mathbf{J}$ Foreign Languages Edu. 07: (2016) 134-135.

[5]D. Wang. "Internet + " under the educational background of micro-class in college English listening and speaking teaching application-taking Shenyang Normal University as an example, J Jiamusi Vocat College. 09 (2016) 387.

[6] W. Yi. The application and reflection of the reversing class in the college English teaching based 
on the micro course - taking the course of English film appreciation as an example, J Qingdao Ocean Univ Occup College. 03 (2016) 54-59.

[7]J. H. Wang. The feasibility analysis of the application of the skip class in the college English teaching in private colleges, Rural Eco Technol. 24 (2016) 278.

[8] D. Wang, Y. Zhang, Research on the application of "tilting classroom" based on micro - course in college English listening and speaking teaching, J Lanzhou Edu College. 01 (2017) 146-148.

[9] D. M. Fu, Guamili-Abulaiti, Discussion on the application of micro - course in the teaching mode on the basis of the background of college English teaching reform, J Kaifeng Inst Edu. 10 (2016) 63-64.

[10] Y. M. Chen, The application of reversing classroom mode in college English listening and speaking teaching, Xinjiang Vocational Edu Res. 02 (2016) 41-43.

[11] X. X. Song, Research on the application of mixed learning mode based on micro-course in college English teaching in adult colleges, Beijing Xuanwu Hongqi Amateur Univ J. 02 (2016) $50-52$.

[12] Y. C. Xie, The application of micro-course in college english teaching - a case study of physical education majors in Shenyang Physical Education Institute, Sci Technol Outlook. 15(2014) 81. 